\title{
Social parasitism of queens and workers in the Cape honeybee (Apis mellifera capensis)
}

\author{
Robin F. A. Moritz, H. Michael G. Lattorff, Kendall L. Crous \& Randall H. Hepburn
}

\begin{abstract}
Workers of a queenless honeybee colony can requeen the colony by raising a new queen from a young worker brood laid by the old queen. If this process fails, the colony becomes hopelessly queenless and workers activate their ovaries to lay eggs themselves. Laying Cape honeybee workers (Apis mellifera capensis) produce female offspring as an additional pathway for requeening. We tested the frequency of successful requeening in ten hopelessly queenless colonies. DNA genotyping revealed that only $8 \%$ of all queens reared in hopelessly queenless colonies were the offspring of native laying worker offspring. The vast majority of queens resulted from parasitic takeovers by foreign queens $(27 \%)$ and invading parasitic workers $(19 \%)$. This shows that hopelessly queenless colonies typically die due to parasitic takeovers and that the parasitic laying workers are an important life history strategy more frequently used than in providing a native queen to rescue the colony. Parasitism by foreign queens, which might enter colonies alone or accompanied by only a small worker
\end{abstract}

Communicated by: O. Rueppell

Electronic supplementary material The online version of this article (doi:10.1007/s00265-010-1077-y) contains supplementary material, which is available to authorized users.

R. F. A. Moritz \& H. M. G. Lattorff

Institut für Biologie, Martin-Luther-Univeristät Halle-Wittenberg, Hoher Weg 4,

06099 Halle a.d. Saale, Germany

e-mail: robin.moritz@zoologie.uni-halle.de

\section{R. F. A. Moritz}

Department of Zoology and Entomology, University of Pretoria, Pretoria 0002, South Africa

\section{K. L. Crous \& R. H. Hepburn}

Department of Zoology and Entomology, Rhodes University, P.O. Box 94, Grahamstown 6140, South Africa force is much more frequent than previously considered and constitutes an additional life history strategy in Cape honeybees.

Keywords: Cape honeybee . Parasitic workers . Parasitic queens . Queen rearing

\section{Introduction}

Reproductive hierarchies are the essence of social organization in hymenopteran insect societies. Typically, reproductive division of labor is regulated by establishing a queen caste with reproductive females and one or more worker castes that care for rearing the queens' offspring among many other tasks maintaining the functioning of the colony. Inclusive fitness theory (Hamilton 1964) plausibly explains why workers refrain from reproduction and, instead of producing own offspring, invest in rearing the queen's offspring to enhance their indirect fitness. In honeybees, Apis mellifera, a suite of mechanisms, including physical dominance and pheromonal signals as well as policing behavior of workers regulate the reproductive hierarchies suppressing major intracolonial conflict among the workers. Whenever queen control is relaxed, workers can activate their ovaries and produce own offspring. This typically occurs when the queen is lost resulting in worker produced offspring, which is usually of the male sex because unfertilized eggs remain haploid and develop into males (arrhenotoky). In some species, however, laying workers can produce female offspring (thelytoky), a phenomenon first observed in the Cape honeybee Apis mellifera capensis (Onions 1912) but more recently also found in various ant species (Pearcy et al. 2006; Dobata et al. 2008). The mode of parthenogenesis has been studied in 
some detail in A. mellifera capensis workers (Neumann and Moritz 2002; Hepburn and Radloff 1998) and has been found to be controlled by a single gene (Lattorff et al. 2005, 2007). Although queens also occasionally lay thelytokous eggs (Oldroyd et al. 2008; Allsopp et al. 2010), this is the exception sometimes observed in A. mellifera capensis queens (Velthuis et al. 1990), whereas laying workers of the Cape honeybee perform obligate thelytokous parthenogenesis (Anderson 1963). The consequences of this type of reproduction are far reaching since worker policing (the removal of worker-laid eggs by other workers, Ratnieks 1988) is no longer adaptive even in the presence of the queen (Greeff 1996) and indeed policing is less well expressed in queen right colonies of Cape honeybees (Moritz et al. 1999).

Thelytoky also sets the stage for the evolution of social parasitism of laying workers (Härtel et al. 2006). In addition to the intracolonial selection among workers (Moritz et al. 1996a, b, 2000; Simon et al. 2005), foreign workers can also enter the colony, kill the queen, and establish themselves as social parasitic pseudoqueens (Neumann et al. 2003; Moritz et al. 2003). Often, these colonies eventually collapse because only social parasitic workers that do not participate in the non-reproductive working tasks but only engage in egg-laying are reared (Hillesheim et al. 1989). Hence, brood rearing deteriorates as the original host workers gradually disappear and die. In some cases, however, offspring of these parasitic workers can be reared to queens (Moritz et al. 1996a, b; Jordan et al. 2008; Oldroyd et al. 2008; Allsopp et al. 2010; Holmes et al. 2010), which take over the host colony, mate, and produce worker offspring. These sexually produced workers do not show the parasitic phenotype in the presence of the queen and colony homeostasis is re-established (Neumann and Moritz 2002).

In addition to these takeovers by parasitic workers, colonies can also be parasitized by other colonies. Colony mergers are frequent observations in various subspecies of African honeybees (Hepburn and Allsopp 1994) where a swarm moves in to an existing colony and the invading queen kills the resident queen to take over the colony. We here study which parasitic pathways are common in honeybee colonies with thelytokous laying workers by monitoring the fate of ten de-queened colonies and the outcome of the emergency queen rearing over a 2-month period.

\section{Materials and methods}

\section{Honeybee samples}

Ten unrelated colonies of A. mellifera capensis from Heidelberg, Western Cape Province, South Africa were established in an apiary at Slaaikraal, about $15 \mathrm{~km}$ from
Grahamstown, South Africa within the endemic range of the subspecies. Hives were grouped with up to four colonies in a group and the three groups separated by $5 \mathrm{~m}$ each. Hive entrances were rotated $90^{\circ}$ from each other to minimize drifting between hives. The study was conducted during the autumn months, March through May. All colonies were kept in standard ten-frame Langstroth hives, initially with all ten frames. Additional frames of honey were provided for colonies which appeared weaker. Queens were removed from all ten colonies at the onset of the experiment and stored in $70 \%$ ethanol for later DNA extraction. The brood frames and honey stores were assessed as well as the presence of drones.

For full development of a Cape honeybee queen from the time of oviposition until the eclosion of a virgin queen, a minimum of 13 days is required. It was for this reason that colonies where checked at 8-day intervals for 10 weeks. Any sealed queen cells were removed and the larvae or pupae stored in ethanol for subsequent DNA extraction. If a queen cell was uncapped the location of the cell on the comb was noted and left until the following week to be then sampled. In addition to the queen samples we also took worker samples $(\ll=48)$ of the colonies to test for the maternity of the worker force of the colony at the beginning of the experiment (week 0), after three, and after 6 weeks. In these colonies, the brood situation was assessed to ascertain the onset of eggs laid by workers in the colony. Eggs and larvae were noted as well as cells containing more than one egg, suggesting the presence of laying workers.

\section{DNA analyses}

DNA was extracted from a hind leg or larval sections using $100\left(0.1 \mathrm{Chelex}^{\circledR}(5 \%)\right.$ and $5\left(\mathbf{r l}\right.$ proteinase $\mathrm{K}$ at $55^{\circ} \mathrm{C}$ for $60 \mathrm{~min}$, subsequently heating to $99^{\circ} \mathrm{C}$ for $15 \mathrm{~min}$ (Walsh et al. 1991). We used the three linked marker sets of the standard microsatellite tool kit for studying honeybee populations (Shaibi et al. 2008). These include two loci on chromosome 3 next to the sex locus (csd) spanning $11.6 \mathrm{~kb}$ or $0.2 \mathrm{cM}$ (HB-SEX-01, HB-SEX-03). The second set comprises four loci (HB-THE-02, HB-THE-03, HB-THE-04, HB-THE-05) spanning $11.2 \mathrm{~kb}$ or $0.19 \mathrm{cM}$ on chromosome 13 next to the thelytoky gene (Lattorff et al. 2007) which controls the mode of worker parthenogenesis. A third set on chromosome 16 spans $16.4 \mathrm{~kb}$ or $0.28 \mathrm{cM}$ in a "gene desert" expected to be selectively neutral (HB-C16-01, HB-C16-02, HB-C16-03, HB-C16-05, AC006). Multiplex PCR-reactions were as in (Kraus et al. 2007) and $10|\boldsymbol{i}|$ reaction solution contained $7.35\left(\mathbf{0 . 1} \mathrm{H}_{2} \mathrm{O}, 1\right.$ (0.1 $10 \mathrm{x}$ buffer $(15 \mathrm{mM} \mathrm{MgCl}), 0.2$ lil $10 \mathrm{mM}$ dNTPs, 0.2 (d 10 (oM primer (5'-fluorescence label, TET, HEX, FAM), 0.05 (d Taq DNA polymerase, and $1|i|$ DNA template. The PCR temperature program was as follows: 5 min denaturation at $95^{\circ} \mathrm{C}, 35$ cycles of $30 \mathrm{~s}$ at $95^{\circ} \mathrm{C}, 30 \mathrm{~s}$ 
annealing at $54^{\circ} \mathrm{C}, 1 \mathrm{~min}$ extension at $72^{\circ} \mathrm{C}$, and $20 \mathrm{~min}$ final elongation at $72^{\circ} \mathrm{C}$. Genotyping was done in a MegaBace ${ }^{\circledR}$ automatic sequencer following the instructions of the manufacturer and using the analysis software MegaBACE Fragment Profiler version 1.2 for genotype scoring.

\section{Genotype interpretation}

Our aim was to assign the maternity of a given individual to the original queen of the colony, a native worker, a parasitic worker, or a parasitic queen. Hence, we combined the information from the time line of our hive manipulations with those of the microsatellite genotyping. The time of sampling after queen removal in combination with the developmental stage of the sample (larvae, pupae, or adult) are indicative of whether a larva is queen or laying worker offspring. Four days after queen removal, eggs can no longer be queen-derived. In addition, the genotype was used to infer the genealogy of the sampled individuals. Genotype information is highly accurate as we used not only the information from individual loci, but also the tight linkage to other loci on the same chromosome. This reduced the error for having the identical haplotype marker set for two different chromosomes to less than $10^{-10}$ just for chromosome 13 alone based on the five-linked loci with an average number of 23 alleles per locus (Shaibi et al. 2008). We also included marker loci directly associated with the sex-determining gene csd, to genetically confirm the sex of larvae or pupae in the queen cells, as these have to be heterozygous for these alleles. If the age of a sampled individual was less than the time span of the queen removal but matched the genotype of the removed queen, we concluded that laying daughter workers of the removed queen had produced the offspring. If the samples matched those of a resident queen, we assumed that all offspring was queen-derived. If the sampled individuals' genotypes did not match the one of the removed queen, we assumed that they were produced by parasitic thelytokous laying workers.

\section{Results}

\section{Colony fate}

Table 1 shows the sequence of the 130 emergency queens reared in the ten colonies. Already during sampling there was repeated suggestive evidence of laying worker activity because of multiple eggs being laid in brood cells (in colony 1). Two colonies absconded within the observation period: colony 2 after 6 weeks and colony 8 after 9 weeks. In five cases, twice in colony 1 and once each in colonies 4 , 6 , and 7 , we found an adult queen in the colony although all queen cells had been removed in the previous colony inspection suggesting that these were due to invasive queens; however, just based on the apicultural manipulation it is difficult to exclude that during colony inspections queen cells had not been overlooked. The genotyping is therefore essential to confirm the origin of these queens.

\section{Maternity tests}

\section{Queen genotypes}

Figure 1 shows the number of emergency queens reared and maternity based on genotype analysis. All contents of queen cells, larvae as well as pupae, were genetically confirmed to be females and heterozygous at the markers linked to the sex-determining gene csd. The first 54 queens reared within the first week after queen removal almost exclusively belonged to the native colony in all test colonies. These were most likely all produced by the original queen and represent the typical emergency queens reared; however, in one colony (no. 10) three queen larvae reared from parasitic worker offspring were detected within this first week of queenlessness. Within the first 3 weeks queen rearing from either native queen or worker produced larvae slowly diminished and the proportion of queens reared from parasitic queen or worker larvae increased. After 4 weeks no queen rearing activity by native queens or workers was observable and all queens reared were produced by parasitic queens or workers. During the whole experiment 5 queen takeovers were observed, 4 of them occurred during the first 3 weeks in colonies 1, 4, 8 and 9. (the latter two inferred from the genotyping data). The adult queens found in colonies 6 and 7 were offspring from native laying workers. Overall (including first week's emergency queens), the majority of the offspring queens $(80 \%)$ were reared from queen-laid eggs (either resident or parasitic) and only $20 \%$ of all emergency queens were reared from laying worker offspring (Fig. 2); however, if we only consider the queens reared in hopelessly queenless colonies (starting at day 15), significantly more parasitic queens (laid by parasitic queens or workers) $(\mathrm{n}=50)$ were reared than native queens (laid by native queens or workers) $\left(\mathrm{n}=18, \mathrm{X}^{2}=15.06\right.$; df $\left.1 \mathrm{p}=0.001\right)$. Queen genotypes were used to infer the potential origin of parasitic queens and workers testing if the parasitic takeovers originated from the test apiary. All parasitic queens could be excluded to be offspring of the colonies on the apiary. The 24 parasitic workers which each produced one queen offspring were all from outside colonies except for three which could not be excluded to have originated from the apiary. One parasitic worker in colony 3 potentially is offspring of the native queen of colony 4 . Two other parasitic workers detected in colony 4 might be descendants of other native queens; however, the genotyping resolution is low in these cases due to missing data and does not allow for an accurate assignment of those individuals. 


\begin{tabular}{|c|c|c|c|c|c|c|c|c|c|c|c|c|}
\hline \multicolumn{2}{|c|}{$\begin{array}{l}\text { day } \\
\text { colony \# }\end{array}$} & & 8 & \multicolumn{2}{|c|}{15} & \multicolumn{2}{|c|}{22} & 29 & 36 & 43 & 51 & 64 \\
\hline 1 & $\rightarrow$ & & 0 & & 0 & - & & 6 & 0 & 0 & 0 & 1 \\
\hline 2 & $\rightarrow$ & & 4 & & 0 & ( & & 0 & 0 & $\dagger$ & $\dagger$ & $\dagger$ \\
\hline 3 & $\rightarrow$ & & 6 & & 1 & 2 & & 6 & 0 & 2 & 0 & 0 \\
\hline 4 & $\rightarrow$ & & 0 & & 0 & - & & 15 & 1 & 1 & 2 & 0 \\
\hline 5 & $\rightarrow$ & & 4 & 1 & 1 & 1 & 1 & 1 & 2 & 0 & 1 & 0 \\
\hline 6 & $\rightarrow$ & & 1 & & 0 & I & & (I) & $\rightarrow$ & 10 & 0 & $\dagger$ \\
\hline 7 & $\rightarrow$ & & 5 & & 0 & 1 & & 0 & 0 & (I) & $\rightarrow$ & 0 \\
\hline 8 & $\rightarrow$ & & 8 & 1 & $\rightarrow$ & 2 & & 2 & 2 & 2 & 0 & 0 \\
\hline 9 & $\rightarrow$ & 4 & $\rightarrow$ & & 0 & - & & 3 & 0 & 1 & 0 & 0 \\
\hline 10 & $\rightarrow$ & 8 & 3 & & 0 & 4 & 2 & 0 & 0 & 0 & 0 & $\mathbf{0}$ \\
\hline
\end{tabular}

The numbers are number of queen larvae/pupae sampled (white cells=native queen/worker offspring; black cells=parasitic queen offspring, gray cells= parasitic worker offspring). Two weeks after queen removal, larvae and eggs with native genotypes are produced by native laying workers. The arrow $(\rightarrow)$ indicates the removal of an adult queen, $f=$ colony absconded. (1) Inferred from genotype data of adult queen removed 1 week later

\section{Worker genotypes}

In the sample taken in week 0 , all workers $(n=48)$ belonged to the resident queens in all four tested colonies. In week 3 , all four colonies had been taken over by a parasitic queen. In one colony, all sampled workers were offspring of the original queen. In the other three colonies, only one out of 12 genotyped workers was identified as offspring of the parasitic queen. Overall, this resulted in an estimate of $6.6 \%$ (95\% confidence interval for binomial distribution, 1.4$18.3 \%$ ) parasitic queen offspring in the worker sample which is significantly less than the resident workers (Fig. 3). This implies that workers produced by the parasitic queens were rare or absent in the parasitized colonies. Thus, the colony takeovers were by very small parasitic swarms and in one case we cannot exclude the possibility that a single queen took over the colony without any workers of herself. After 6 weeks, the genotyped workers $(n=20)$ were predominantly offspring of the parasitic queens and the old resident workers were now in the minority (17.6\%; 95\% C.I., 3.8-43.3\%)

\section{Discussion}

Emergency queen rearing is an important element in the life history of a honeybee colony. It ensures colony survival and indirect fitness of the sterile workers because a related queen is raised and will eventually take over the colony.
This is a very solid mechanism for queen replacement and, also in our experiment, nine colonies had reared native emergency queen larvae 1 week after the removal of the original queen, but one colony (no. 2) had failed, which again is typical for any complex process in biology, they sometimes do not work. In these cases, where emergency queen rearing fails (as in our experiments), laying workers appear in due course in all A. mellifera subspecies to produce worker-laid offspring. This process still maintains a within-colony relatedness of at least half sibs between the non-reproductive workers of the colony and the drones (under arrhenotoky) or queens (under thelytoky, the special case of A. mellifera capensis) reared in the colony. Our results show that whenever this classical pathway for laying workers fails and the colony remains queenless the role of queen parasitism increases dramatically. Our experimental manipulations caused hopelessly queenless colonies, which had been prevented from successful requeening within 2 weeks after queen loss. In these cases, the major life history trajectory of the tested colonies was death through usurpation by parasitic workers or invasive queens.

Our data show that, in particular, takeovers of queenless colonies by parasitic queens are more common than previously anticipated. In one third of all cases, foreign queens established themselves in the test colonies. The principle of colony takeovers by foreign queens is not a novel phenomenon as such, since colony mergers have been reported previously for African honeybees other than A. mellifera capensis (Hepburn 
than twice as many queens than native laying workers. This fits well with the observations of Allsopp et al. (2010) who also found that the majority of worker produced queens were offspring of worker parasites not native to the colony. The genotype assignment of parasitic laying workers showed that only one of 24 workers matched a genotype from experimental colonies. This reflects the high dispersal capabilities of A. mellifera capensis workers (Neumann et al. 2001). Previous models (Tribe 1983; Moritz 1989; Greeff 1996) have considered worker thelytoky to be primarily an adaptation to a high frequency of queen loss. Our results now show that although thelytokous parthenogenesis of workers can replace the original queen, a potentially selective advantage of laying workers may be through usurpation of queenless colonies which failed in emergency queen rearing and the establishment of an offspring queen in a host colony through social parasitism. Nevertheless, compared with the frequency and success of parasitic queens, the impact of socially parasitic workers on queenless colonies of the Cape honeybee seem to be less important than previously thought.

Acknowledgements We are grateful to Juliane Kuhfuß and Petra Leibe for helping with the genotyping. Funding was provided by the DFG (RFAM).

\section{References}

Allsopp MH (1992) The capensis calamity. S Afr Bee J 64:52-55

Allsopp MH, Beekman M, Gloang RS, Oldroyd BP (2010) Maternity of replacement queens in the thelytokous Cape honey bee Apis mellifera capensis. Behav Ecol Sociobiol 64:567-574

Anderson RH (1963) The laying worker in the Cape honey-bee Apis mellifera capensis. J Apicult Res 2:85-92

Dobata S, Sasaki T, Mori H, Hasegawa E, Shimada M, Tsuji K (2008) Cheater genotypes in the parthenogenetic ant Pristomyrmex punctatus. Proc Roy Soc B 276:567-574

Greeff JM (1996) Effects of thelytokous worker reproduction on kin selection and conflict in the Cape honeybee, Apis mellifera capensis. Philos Trans R Soc Lond B 351:617-625

Hamilton WD (1964) Genetical Evolution of Social Behavior I. J Theor Biol 7:1-16

Härtel S, Neumann P, Raassen FS, Moritz RFA, Hepburn HR (2006) Social parasitism by Cape honeybee workers in colonies of their own subspecies (Apis mellifera capensis Esch.). Insect Soc 53:183-193

Hepburn HR, Allsopp MH (1994) Reproductive conflict between honeybees, usurpation of Apis mellifera scutellata colonies by Apis mellifera capensis. S Afr J Sci 90:247-249

Hepburn HR, Radloff SE (1998) Honeybees of Africa. Springer, Berlin

Hillesheim E, Koeniger N, Moritz RFA (1989) Colony performance in honeybees (Apis mellifera capensis Esch.) depends on the proportion of subordinate and dominant workers. Behav Ecol Sociobiol 24:291-296

Holmes MJ, Oldroyd BP, Allsopp MH, Lim J, Wossler T, Beekman M (2010) Maternity of emergency queens in the Cape honey bee, Apis mellifera capensis. Mol Ecol 19:2792-2799

Jordan LA, Allsopp MH, Oldroyd BP, Wossler TC, Beekman M (2008) Cheating honeybee workers produce royal offspring. Proc Roy Soc Lond B 275:345-351
Kraus FB, Büchler R, Siede R, Berg S, Moritz RFA (2007) Trade-off between survival and male reproduction in Varroa destructor infested honeybee colonies (Apis mellifera). Ethol Ecol Evol 4:263-273

Lattorff HMG, Moritz RFA, Fuchs S (2005) A single locus determines thelytokous parthenogenesis of laying honeybee workers (Apis mellifera capensis). Heredity 94:533-537

Lattorff HMG, Moritz RFA, Crewe RM, Solignac M (2007) Control of reproductive dominance by the thelytoky gene in honeybees. Biol Lett 3:292-295

Moritz RFA (1989) Colony level and within colony level selection in honeybees. A two allele population model for Apis mellifera capensis. Behav Ecol Sociobiol 25:437-444

Moritz RFA, Kryger P, Allsopp M (1996a) Competition for royalty in bees. Nature 384:31

Moritz RFA, Kryger P, Allsopp M (1996b) Competition for royalty in bees. Nature 384:522

Moritz RFA, Kryger P, Allsopp M (1999) Lack of worker policing in the Cape Honeybee (Apis mellifera capensis). Behaviour 136:1079-1092

Moritz RFA, Simon UE, Crewe RM (2000) Pheromonal contest between honeybee workers (Apis mellifera capensis). Naturwissenschaften 87:395-397

Moritz RFA, Pflugfelder J, Crewe RM (2003) Lethal fighting between honeybee queens and parasitic workers (Apis mellifera). Naturwissenschaften 90:378-381

Neumann P, Radloff SE, Moritz RFA, Hepburn HR, Reece SL (2001) Social parasitism by honeybee workers (Apis mellifera capensis Escholtz): host finding and resistance of hybrid host colonies. Behav Ecol 12:419-428

Neumann P, Moritz RFA (2002) The Cape honeybee phenomenon: the sympatric evolution of a social parasite in real time? Behav Ecol Sociobiol 4:271-281

Neumann P, Radloff SE, Pirk CWW, Hepburn HR (2003) The behaviour of drifted Cape honeybee workers (Apis mellifera capensis), predisposition for social parasitism? Apidologie 34:585-590

Oldroyd BP, Allsopp MH, Gloag RS, Lim J, Jordan LA, Beekman M (2008) Thelytokous parthenogenesis in unmated queen honeybees (Apis mellifera capensis), central fusion and high recombination rates. Genetics 180:359-366

Onions GW (1912) South African "fertile-worker bees". S Afr Agric J 1:720-728

Pearcy M, Hardy O, Aron S (2006) Thelytokous parthenogenesis and its consequences on inbreeding in an ant. Heredity 96:377382

Ratnieks FLW (1988) Reproductive harmony via mutual policing by workers in eusocial hymenoptera. Am Nat 132:217-236

Schneider SS, Deeby T, Gilley DC, DeGrandiHoffmann G (2004) Seasonal nest usurpations of European colonies by African swarms in Arizona, USA. Insect Soc 51:359-364

Shaibi T, Lattorff HMG, Moritz RFA (2008) A microsatellite DNA toolkit for studying population structure in Apis mellifera. Mol Ecol Res 8:1034-1036

Simon UE, Moritz RFA, Crewe RM (2005) Reproductive dominance among honeybee workers in experimental groups of Apis mellifera capensis. Apidologie 36:413-419

Tribe GD (1983) What is the Cape bee? S Afr Bee J 55:77-87

Velthuis HHW, Ruttner F, Crewe RM (1990) Differentiation in reproductive physiology and behaviour during the development of laying worker honey bees. In: Engels W (ed) Social insects: an evolutionary approach to castes and reproduction. Springer Verlag, Berlin, pp 231-243

Walsh PS, Metzger DA, Higuchi R (1991) Chelex 100@ as a medium for simple extraction of DNA for PCR-based typing from forensic material. Biotechniques 10:506-513 